Leisure Services UK 


\section{Leisure Services UK}

An Introduction to Leisure, Entertainment and Tourism Services

Edited by Norman Borrett

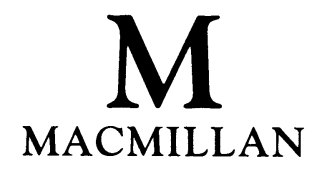


Selection and editorial matter (C) Norman Borrett 1991

Individual chapters (C) Oliver Bennett, Dr Graham Nicholson,

Anne Partington-Omar, Dr Terry Stevens, Tony Gentil,

Stephen Rennie, Norman Borrett, John Walsh-Heron 1991

All rights reserved. No reproduction, copy or transmission of this publication may be made without written permission.

No paragraph of this publication may be reproduced, copied or transmitted save with written permission or in accordance with the provisions of the Copyright, Designs and Patents Act 1988, or under the terms of any licence permitting limited copying issued by the Copyright Licensing Agency, 90 Tottenham Court Road, London W1P 9HE.

Any person who does any unauthorised act in relation to this publication may be liable to criminal prosecution and civil claims for damages.

First published 1991 by

MACMILLAN EDUCATION LTD

Houndmills, Basingstoke, Hampshire RG21 2XS

and London

Companies and representatives

throughout the world

Copy-edited and typeset by Povey/Edmondson

Okehampton and Rochdale, England

British Library Cataloguing in Publication Data

Leisure Services UK.

1. Great Britain. Leisure facilities. 2. Great Britain.

Tourist attractions

I. Borrett, Norman

306.48

ISBN 978-0-333-52554-8 ISBN 978-1-349-11621-8 (eBook)

DOI 10.1007/978-1-349-11621-8

$\begin{array}{llllllllll}10 & 9 & 8 & 7 & 6 & 5 & 4 & 3 & 2 & 1\end{array}$

$\begin{array}{llllllllll}00 & 99 & 98 & 97 & 96 & 95 & 94 & 93 & 92 & 91\end{array}$ 


\section{Contents}

Acknowledgements

vi

Notes on the Contributors

vii

Introduction

$\mathrm{xi}$

1 Entertainment and the Arts

Oliver Bennett

2 Libraries

55

Dr Graham Nicholson

3 Museums

Anne Partington-Omar

4 Countryside Recreation

Dr Terry Stevens

5 Parks and Amenities

Tony Gentil

6 Play and Playwork

Stephen Rennie

7 Sport and Physical Recreation

Norman Borrett

8 Tourism

John Walsh-Heron

Useful Addresses

Index 


\section{Acknowledgements}

The editor and publishers wish to thank the following for permission to use copyright material in the text of this book. The Policy Studies Institute, for data in Tables 1.1, 1.3, 1.4, 1.6 and 3.1, from Cultural Trends 1989 (1989) and for Table 3.3 from Cultural Trends into the Eighties (1990); Library and Information Statistics Unit, Loughborough University, for CIPFA data in Tables 2.1 and 2.2, and Figure 2.1, from M. Donoghue and P. H. Mann, Public Library Statistics 1987-88: A Trend Analysis (1988); NALGO, for data in Table 5.1, from Governing Bodies of Sport (1985); Institute of Public Finance Ltd, for CIPFA data in Tables 5.2 and 7.4, from Leisure and Recreation Statistics Estimates, 1985 and 1988-9; Forestry Commission, for data in Table 5.3, from 'Recreation in Forests' in The Forestry Commission and Recreation Commission Policy Paper No. 2 (1988); Play Board, for data in Table 6.1, from Survey of play staff working in 11 local authority areas (1986), and in Table 6.2 and Figure 6.1, from Playwork Training, Qualifications, Conditions of Service: a survey of playstaff employees and local authorities, D. Clarke, J. Coffin and C. Parkinson, Play Board/LGTB, August 1985; Sports Council, for data in Tables 7.1 and 7.2, from Sport in the Community: Into the 90s (1988), and in Table 7.3 from the Annual Reports of the Sports Council, the Sports Council for Wales, the Scotish Sports Council and the Sports Council for Northern Ireland; RSL Sportscan, for data in Table 7.5, from Marketing/ Sportscan Quarterly Survey (May 1989); The Henley Centre, for data in Tables 7.6 and 7.7, from Leisure Futures (1986); BTA for data in Table 8.1, from National Facts of Tourism (1989), in Table 8.2, from Britian's Tourism (September 1989), and in Figure 8.1, from British Travel Brief (1987); Countryside Commission, for Figure 4.1, from Survey of Countryside Recreation (1986), and Figure 4.2, from Recreation 2000 - Enjoying the Countryside ... (May 1987); Unwin Hyman Ltd, for Figure 4.3 from Countryside Conservation (1981); Central Council of Physical Recreation for data from Down with Rates (1990).

Every effort has been made to trace all the copyright-holders, but if any have been inadvertently overlooked the publishers will make the necessary arrangement at the earliest opportunity.

The editor would like to acknowledge the skill and dedication of Sue Davies who typed numerous drafts of the manuscript. Thanks Sue for your good humour and tolerance. 


\section{Notes on the Contributors}

Oliver Bennett is Head of Arts Administration at Leicester Polytechnic, and Chief Executive of the Phoenix Arts Centre. He has worked in Arts administration for over 15 years and has served as a member of the Arts Council of Great Britain's Regional Committee and Combined Arts SubCommittee. As well as teaching a range of undergraduate studies in Arts Administration, he is also developing an MA in European Arts and Cultural Policy, with the support of UNESCO and the European Commission. He sets and marks examination papers for the Institute of Leisure and Amenity Management (ILAM). He regularly directs student performance work, and plays tenor saxophone in a small jazz ensemble.

Norman Borrett is Senior Lecturer in Leisure and Recreation Studies at Bradford and Ilkley Community College. Prior to moving to Yorkshire he worked in both the Teaching Studies Department and the Business School at the Polytechnic of North London, where he was course tutor for the BTEC Higher National Diploma in Leisure and Tourism, and the MA in Leisure and Recreation Studies. He has served as a member of the Executive Committee of the Leisure Studies Association, and currently is a BTEC Moderator for courses in leisure and tourism. He has had experience preparing students for ILAM examinations and currently teaches leisure policy and leisure management.

Anthony Gentil is Deputy Head of Horticulture at Cheshire College of Agriculture. He has published material for Capel Manor Open Learning Unit, NALGO correspondence course leading to the ILAM Certificate, Ashford Press and Manchester Open Learning Unit, and various trade publications. He has experience as an examiner for ILAM and for the Master in Arboriculture of the Royal Forestry Society, and is a BTEC Moderator in Leisure Studies. He is a member of the British Institute of Management, and a Fellow of the Arboriculture Association and the Linnean Society.

Dr Graham Nicholson is Director of Leisure Services for Bury Metropolitan Borough Council. After completing his Doctorate in Tudor English History at Cambridge, he held a number of museum appointments, and 
was for several years Curator of the Castle Museum in York. He was until recently responsible for cultural services in Stockport, which included everything from public libraries and country houses to 'rock and roll' concerts. He has particular interests in marketing local history collections and archives, publishing in the library service, and the training of library staff.

Anne Partington-Omar is Assistant Chief Leisure Services Officer (Heritage and Culture) for Bury St Edmunds. Prior to starting her career in museum services, she trained as a microbiologist, and initially worked as a technical aquarist with Bolton Borough Council. She worked in Museum Education for Hull City and Doncaster M.B.C. before taking up a position as Curator for Epping Forest District Council. She has served as an Associate Member and Councillor of the Museums Association, Chairman of the MA's Education Board, and is currently a member of the Standing Registration Committee of the Museums and Galleries Commission. Her current responsibilities cover Museums, Arts, Tourism, Entertainments and Festivals.

Stephen Rennie is Director of The Play Co-operative Ltd (Playtech), a company concerned with training, research and the sale of goods and services in the field of play throughout the UK. Prior to joining Playtech, he was Regional Play Officer for Play Board. He has had an extensive career in children's play and has worked as a Youth Leader, Play Leader, and Play Officer for a number of Local Authorities. He has published widely, lecturers in Playwork at Leeds Polytechnic, and is External Assessor for the National Institute of Playwork.

Dr Terry Stevens is Head of the Department of Tourism, Leisure and Health Care at West Glamorgan Institute of Higher Education, and Business Adviser to the Wales Tourist Board. He is a member of a number of important committees including the Countryside Commission's Committee for Wales, the Wales Tourist Board Attractions Advisory Committee, and the Council of Europe Working Party on Cultural Tourism. He has extensive consultancy experience in the UK and overseas and has published over fifty articles in journals and books. As well as being a member and Examiner for ILAM, he is an External Examiner for the MSc and $\mathrm{PhD}$ programmes at the University of Reading, and a Fellow of the Tourism Society.

John Walsh-Heron was Head of Trade and Consumer Affairs for the Wales Tourist Board. He works on a number of committees including City and Guilds, the Council for National Academic Awards, and the British Tourist Authority. Following his training in Hotel Management, he worked for the Wales Tourist Board since 1970 and was responsible for Board policy relating to quality assurance, training, education, advisory services, and legislation. He established the first National 
Tourist Board Inspection System in mainland UK and developed, in conjunction with the caravan industry, the basis for the first Grading System of Caravan Parks in the world. John Walsh-Heron has recently been appointed Managing Director of Tourism Quality Services Ltd, a company set up by the Wales Tourist Board to operate its inspection and advisory services. 


\section{Introduction}

\section{The Development of Leisure Services}

Leisure services comprise public, commercial and voluntary organisations that influence every aspect of our lives: from the beginning of early play, to the cemeteries and crematoria that mark our final resting place; from the private spheres of home and family, to the public domain of stadia and theatre; from quiet reflections in a library or museum, to noisy and energetic pursuits on our playing fields or in discotheques. Whoever we are, whatever we do, and no matter how varied or limited our tastes, leisure services are there to supply our wants and nurture our needs.

Yet, the traditional leisure services that provide for us today have not always existed in their current forms, and the relationship between the various sectors of leisure provision has undergone substantial change. Two centuries ago public funding of leisure services hardly existed. The upper class fenced areas of land for their private use, developed various facilities for their own cultural advancement such as botanical gardens, libraries, museums, and art galleries, and sought to segregate themselves from the amusements of the masses. The poor took their leisure in the beer houses, in the streets, and at fairs and festivals. Public houses often formed the main centres for leisure activities including many kinds of collectors' clubs and societies, as well as events such as bowling, wrestling, boxing, horse-racing, card playing, and dancing.

The streets of the developing towns and cities became centres of attraction for entertainment of many kinds: buskers, preachers, Punch and Judy shows, music, bull baiting, and even public hangings. The streets were also the playgrounds for many children. At this time there was little public provision for leisure. However, by the middle of the nineteenth century, middle-class reformers including the Church and the police were aware that there was a great deal of drunkenness and coarseness within working-class recreation. Individuals and groups from the middle class decided to try and improve the leisure pastimes of the poor and make them more wholesome. Gradually, museums, public parks, libraries, and musical facilities were opened up to all sections of society. The government began to contribute money to secure open 
spaces for public use and to develop provision for the poor, and with the support of wealthy benefactors, a multitude of new facilities and events were established.

Supported by major technological advancements in printing, lighting, heating and transportation, the recreational opportunities for the masses underwent substantial change in a short period of time. In this book, this period forms a backcloth against which leisure services will be explored.

The 1990s will prove a challenging and exciting period for leisure services. Within the last few years changes in the economic and political environment have forced the public, commercial and voluntary providers to critically assess aspects of policy, planning and delivery. Public facilities have become privatised and are now open to private management through competitive tendering, commercial companies have developed interests in a wide variety of leisure concerns and sought partnership agreements with the public sector, and many voluntary and public bodies now make use of commercial sponsorship. The public sector has been forced to become more accountable in terms of economic efficiency and value for money, voluntary clubs and societies are encouraged to develop more efficient management methods, and the commercial sector has grasped opportunities to utilise new technology to improve profitability and develop exciting new leisure experiences.

It was in the mid 1960s that Michael Dower depicted four great waves engulfing society. The first three waves had already broken across the face of Britain. These were, the rapid development of towns during the period of the Industrial Revolution, the development of the railways, and the growth of car-based suburbs. The fourth wave was on the horizon, and was to be the world of leisure. It has been suggested that we are now caught in the tidal force of such a wave and that the society of leisure is upon us. There is a great deal of evidence to support such a claim - higher incomes, better communications, more leisure time, longer holidays, earlier retirement, and better facilities and services for leisure. However, there is a growing awareness among researchers that this picture is not as simple as it first appears.

There are, for example, major differences in opportunity in society today. There are those in secure, well-paid jobs, and those suffering many deprivations including poor housing and unemployment. There are sections of society suffering discrimination in various forms which makes access to leisure services difficult. There are also fundamental differences between leisure opportunities in the countryside compared with inner city environments. Increasing numbers of workers take second jobs, in many cases due to poor pay, and there are growing numbers of double-income households. Life can be viewed as a constant struggle for a limited number of resources and goods. Some are fortunate and have high disposable incomes, plenty of free time, and high levels of personal freedom. Others do not. 
Within this book, the struggle for resources and the identification of priorities within an era of change will be discussed. Should more money be given to the development of popular arts, or should limited resources be concentrated on protecting a heritage based on 'high culture'? Should the countryside be utilised to build new towns and villages and better leisure and entertainment complexes, or should the countryside be protected from developers and tourists? What are the implications for a commercially-driven, deregulated broadcasting system? What would be the consequences of privatising our museums, libraries, parks and waterways? These and other issues will be addressed in the pages that follow.

\section{Structure and Format}

This text will explore the nature of leisure services, and introduce the reader to major aspects of policy, administration and finance associated with provision. The book will be an important text for those on leisure, recreation and tourism courses validated by the Business and Technician Education Council (BTEC) at National, Continuing Education, and Higher National levels, and those who are studying for the Institute of Leisure and Amenity Management (ILAM) examinations. Within a single cover, the book will also provide the new student of leisure and tourism at degree level with a broad understanding of leisure services within the UK.

This book can be used in a variety of ways. It can be read straight through to give the reader a sound overview of leisure services and many of the issues and problems faced by providers and consumers. Alternatively, the reader may wish to refer to a specific chapter that is appropriate to current studies. Those readers who are thirsty for further information and a deeper understanding can attempt some of the exercises and read from the list of recommended texts.

The first chapter, Entertainment and the Arts, has been given additional space as it includes such a diverse range of services. The first part of the chapter contains an exploration of provision and facilities under two broad headings: 'Staying In' - which includes a discussion of television, video, radio, hi-fi, and books; and 'Going Out' - which considers film and cinema, theatre, drama, concerts, opera, dance, cabaret, new variety, and other entertainments. Oliver Bennett goes on to examine consumer expenditure and the funding of Entertainment and the Arts. Finally, the author explores three significant policy issues that demand attention: the relationship between the free market and the cultural industries; the 'new-age' for broadcasting; and the role of public subsidy in support of the Arts. 
Chapters 2 and 3 are shorter, as they deal with more specific areas of leisure servicing. Chapter 2 is on libraries, and Dr Graham Nicholson begins by examining the nature and extent of library provision. In the next section, the management and staffing of libraries, and the main sources of finance are analysed, followed by an examination of service planning and delivery, and an exploration of the crucial role of Information Technology within modern library services. Finally, the author considers 'libraries under threat' and highlights the future prospects for libraries during the 1990s.

Chapter 3 is on museums, and Anne Partington-Omar begins her analysis by considering three broad categories of museum service: national, local authority, and non-public/private museums. The author goes on to ask the question, 'What is a museum?' and contrasts traditional museums with the quickly expanding heritage industry. Following on from an analysis of museum funding, policy and planning, Anne Partington-Omar utilises a case study approach to critically evaluate the contentious issue of admission charges.

Chapters 4 and 5 share a common theme of 'the great outdoors'. In Chapter 4, Dr Terry Stevens begins by exploring the major features of provision in countryside recreation, concentrating on the structure, development and problems associated with our National Parks. In the next two sections the range of activities that take place in the countryside are depicted, as well as the management problems associated with expanding recreational use. Finally, the future prospects for the countryside are considered and the author argues for a sensitive approach to planning and management so that conservation and recreational use can exist in harmony.

Chapter 5, on parks and amenities, complements both Chapter 4 and Chapter 7. The author begins by highlighting the wide range of provisions and facilities that make up parks and amenities. These include urban and regional parks, gardens, sports grounds, allotments, trimtrails, cycleways, zoos, bird gardens, festivals and exhibitions, cemeteries and crematoria. Tony Gentil then reviews two principal organisations concerned with the administration and finance of parks and amenities: the Forestry Commission and the National Trust.

Chapter 6 is concerned with play and playwork. Stephen Rennie initially explores the range of provision in children's play from the public, commercial and voluntary sectors. The author then discusses the support services for supervised play provision, including play resource centres and the variety of national bodies associated with play and playwork. The third part contains a wealth of essential information on legislation, and provides the reader with a clear overview of Acts of Parliament as well as guidance and direction on standards of provision. The final sections are devoted to policy and planning issues in local authorities and future areas of concern for the provision of play. 
Chapter 7 covers sport and physical recreation, and for completeness should be read in conjunction with Chapters 4 and 5. The first part consists of a summary of opportunities and facilities provided by the various sectors, and the importance of partnership agreements between them. Key funding bodies in the public and voluntary sectors are then contrasted with the financial and administrative remits of the commercial providers. In the final section, the future prospects for sport and physical recreation are explored.

The final chapter is on tourism, although it should be noted that many aspects of tourism are considered within other parts of the book. Indeed, the student of tourism would be well advised to note the wide ranging contributions supporting tourism made by areas discussed in previous chapters. John Walsh-Heron begins by exploring the range of accommodation that services tourism such as hotels, motels, caravans, camp sites, and self-catering establishments. The author then highlights the visitor attractions that play such an essential part in tourism, and the role of organisations such as the Tourist Boards and Local Authorities in the administration and finance of the industry. John Walsh-Heron concludes the chapter by considering three essential factors that will shape the future of tourism: population change, the European Community, and the Channel tunnel.

Within each chapter there are a variety of exercises to extend the reader and provide some practical underpinning to the issues raised. In carrying out these exercises the reader will develop a range of skills including information gathering and analysis; quantitative and numerate skills; design and visual discrimination; information processing; problemsolving; and communicating. For those who wish to expand their knowledge, each chapter contains a section on further study in which additional reading is suggested and questions are posed. By attempting the questions the reader will be able to assess his/her understanding of issues raised in the text.

Finally, at the end of the book, there is a selection of addresses of organisations that should provide an additional resource for information on each of the leisure services referred to. These organisations and institutes can provide a wealth of data to support project work and assignments. 
xvi

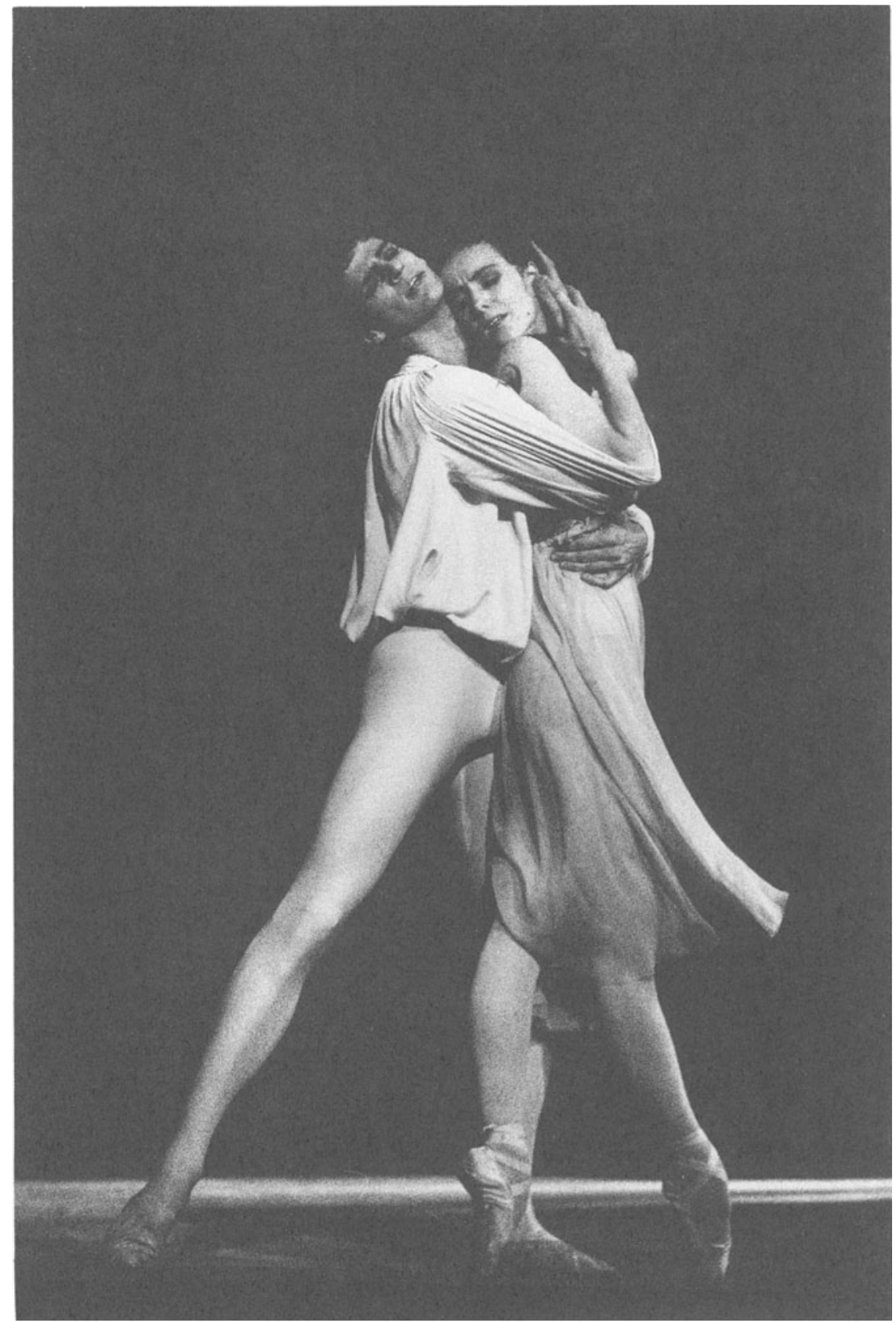

Royal Ballet: Romeo and Juliet (Sylvie Guillam and Jonathan Cope) (photograph by Geoff Howard) 